\title{
Notes
}

\section{Damages for Federal Employment Discrimination: Section 1981 and Qualified Executive Immunity}

For over a decade, Congress has sought to eliminate racial discrimination in employment. The effort began with the passage of Title VII of the Civil Rights Act of 1964, aimed at private employment discrimination. ${ }^{1}$ In 1972 , Congress amended Title VII with the Equal Employment Opportunity Act. ${ }^{2}$ Section $717,3^{3}$ added by that Act, extended Title VII to cover the country's largest employer, the federal government. ${ }^{*}$ The Amendments to Title VII have done little to eliminate federal employment discrimination. ${ }^{5}$ Part of the reason for this failure is that Title VII offers limited monetary relief-a maximum of trwo years back pay recovered from the government treasury. ${ }^{6}$ There is no provision for the personal liability of

1. Pub. L. No. $88-352, \$ \S 701-716,78$ Stat. 241 , prohibits discrimination based on color, sex, religion, and national origin, as well as race.

2. Pub. L. No. 92-261, 86 Stat. 103 (codified at 42 U.S.C. $\$ \$ 2000$ e to $2000 \mathrm{c}-17$ (Supp. IV 1974).

3. 42 U.S.C. § $2000 \mathrm{e}-16$ (Supp. IV 1974).

4. The federal government employs over two and one-half million people. S. Rr.P. No. 92-415, 92d Cong., Ist Sess. 12 (1971). The Act also extended the protection of Title VII to cmployees of state and local gorernments. 42 U.S.C. $\$ 2000$ e(a) (Supp. IV 1974).

5. Prior to the passage of the Equal Employment Opportunity Act, the Senate Committee on Labor and Public Welfare noted that "[s]tatistical evidence shows that minorities and women continue to be denied access to a large number of government jobs, particularly in the higher grade levels." The Committee cited the following percentages of black employees under the General Schedule by grade level: GS-1 through GS-4 (21.8 percent); GS-5 through GS-8 (13.5 percent); GS-9 through GS-11 (5.1 percent); GS-12 through GS-13 (2.7 percent); GS-14 through GS-15 (1.7 percent); GS-16 through GS-18 (1.4 percent). S. REe. No. 92-415, supra note 4, at 13. There is little indication that $\$ 717$ of the Equal Employment Opportunity Act of 1972 has done much to reduce the widespread racial discrimination in federal employment that prompted Congress to amend Title VII in 1972. See V United States Commission on Civil Rights, The Federal Civil Rights Enforcement ErFort-1974, at 15, 86 (1975); Abernathy, Sovereign Immunity in a Constilutional Government: The Federal Employment Discrimination Cases, io Hakv. Civ. Richts-Civ. Lib. L. Rev. 322, 324 (1975).

6. Section $706(\mathrm{~g})$ of Title VII, as amended by the Equal Employment Opportunity Act of 1972, authorizes the district court to grant the following remedies once a finding of discrimination is made:

[To] enjoin the respondent from engaging in such unlawful employment practice and order such affirmative action as may be appropriate, which may include, but 
government officials. This Note argues that such liability can be provided by an alternative remedy for racial discrimination in federal employment-an independent action for damages and back pay against federal officials, brought under 42 U.S.C. $\$ 1981^{7}$ and tailored by the doctrine of qualified executive immunity.

\section{The Inadequacy of Title VII}

The two primary aims of Title VII are deterrence of employment discrimination and compensation for discrimination which is not effectively deterred. ${ }^{8}$ Title VII does not adequately promote either of these objectives. First, since the only monetary relief it provides is back pay, Title VII is of limited effectiveness in deterring employment discrimination. Punitive damages have a recognized deterrent effect, ${ }^{9}$ but the lower courts have held that they are not available under Title VII. ${ }^{10}$ Most important, because the monetary relief in federal suits is

is not limited to, reinstatement or hiring of employees, with or without back pay ... or any other equitable relief as the court deems appropriate. Back pay liability shall not accrue from a date more than two years prior to the filing of the charge with the Commission. Interim earnings or amounts carnable with reasonable diligence by the person or persons discriminated against shall operate to reduce the back pay otherwise allowable.

The Supreme Court has recently held that an award of seniority status retroactive to the date of individual job application is appropriate under $\$ 706(\mathrm{~g})$. Franks $v$. Bowman Transp. Co., 44 U.S.L.W. 4356 (U.S. Mar. 23, 1976). The lower courts have generally determined that punitive and compensatory damages are not available under Title VII. See notes 10, 18 infra.

7. The statute derives from the Civil Rights Act of 1866, Act of Apr. 9, 1866, ch. 31, $\$ 1$, 14 Stat. 27. After reenactment and codification, $\$ 1$ of the 1866 Act now appears as 42 U.S.C. $\$ \$ 1981,1982$ (1970). Section 1981 provides that "[a]ll persons . . . shall have the same right . . . to make and enforce contracts . . . as is enjoyed by white citizens . . .." Originally enacted pursuant to the Thirteenth Amendment, the 1866 Act was reenacted in 1870, two years after the ratification of the Fourteenth Amendment. The reenactment was to ground the Act on both the Thirteenth and Fourteenth Amendments and to make clear that it prohibits actions taken by the states. Section 1981 deals only with the problem of racial discrimination; unlike Title VII, it does not prohibit discrimination based on sex, religion, and national origin. Accordingly, the discussion in this Note is limited to racial discrimination.

For a general discussion of the history of the 1866 Civil Rights Act and the development of $\$ 1981$ as a remedy for private discrimination, sce Jones v. Alfred H. Maycr Co., 392 U.S. 409, 422-44 (1968), and Note, Section 1981 and Private Groups: The Right to Discriminate Fersus Freedom From Discrimination, 84 YAI.E L.J. 1441, 1445-46 (1975).

8. Albemarle Paper Co. v. Moody, 422 U.S. 405, 417-19 (1975).

9. Developments in the Law-Employment Discrimination and Title VII of the Civil Rights Act of 1964, 84 Harv. L. REv. 1109, 1261 (1971); Goldberg, Implying Punitive Damages in Employment Discrimination Cases, 9 Hakv. Civ. Righrs-Civ. Lib. L. Rev. $325,344-45$ (1974).

10. Although punitive damages were awarded by the district court in Stamps v. Detroit Edison Co., 365 F. Supp. 87 (E.D. Mich. 1973), rev'd, 515 F.2d 301 (6th Cir. 1975), the lower courts generally have held that $\$ 706(\mathrm{~g})$ of Title VII does not provide for the award of punitive damages and have refused to award them. E.g., Stamps v. Detroit Edison Co., 515 F.2d 301, 308-10 (6th Cir. 1975); Van Hoomissen v. Xerox Corp., 368 F. 
paid from the agency budget, ${ }^{11}$ the federal official faces no personal liability; his pocket is sealed. He is subject only to the relatively light burden of an injunctive order, a threat which the Supreme Court has termed "little incentive to shun practices of dubious legality."12

Second, Title VII fails to compensate adequately the victims of both federal and private employment discrimination. The original discriminatory practices or ill will engendered by litigation may mean that the employee does not desire reinstatement. ${ }^{13}$ The two-year limit on back pay recovery under Title VII can unjustly deny back pay to a litigant who has been the victim of discrimination for more than two years. ${ }^{14}$ And back pay, even if unlimited, compensates the victim for only part of the injury sustained. The courts have recognized that the loss of a job because of discrimination deprives the employee of more than just a wage. The employee suffers considerable humiliation and mental anguish, ${ }^{15}$ as well as the loss of valuable experience and

Supp. 829, 835-38 (N.D. Cal. 1973), aff'd, 497 F.2d 180 (9th Cir. 1974). But see Dessenberg v. American Metal Forming Co., 6 F.E.P. Cas. 159, 161 (N.D. Ohio 1973) (dictum); Tooles v. Kellogg Co., 336 F. Supp. 14, 18 (D. Neb. 1972) (dictum); Developments in the Law, supra note 9, at 1261-69; Goldberg, supra note 9, at 337.45 (arguing that "punitive damages fit under the umbrella of affirmative action authorized by section $706(\mathrm{~g})$," id. at 339). The Supreme Court has noted the position of the lower courts, but has not decided this issue. Johnson v. Railway Express Agency, 421 U.S. 454, 458-59 n.5 (1975).

11. See 5 C.F.R. $\$ \S ~ 713.271,550.804$ (1974).

12. Albemarle Paper Co. v. Moody, 422 U.S. 405, 417 (1975).

13. See Comment, Tort Remedies for Employment Discrimination Under Tille VII, 54 V.. L. REv. 491, $492-93$ (1968):

[T] he value of reinstatement or an order to hire varies with the nature of the cmployment which was denied the individual. The production-line worker may be able to fade into an impersonal mass of employees, but where relationships with fellowemployees are an important characteristic of a job, reinstatement is less practical. A viable employment relationship clearly cannot be created by court order when the position involves social relations, such as cxist among professional men.

14. Isaacs, A Survey of Remedies Under Title VII, 5 Colum. Humin Rights L. RLv. 437,440 (1973). There was no limit on recovery of back pay when Title VII was first enacted in 1964. Congress imposed the two year "statute of limitations" as part of the 1972 amendments. See 117 Cong. Rrc. 31974 (1971) (statement of Rep. Erlenborn). One proponent of the two year limitation explained that it was needed "so that back-pay awards cannot be rendered in the year 2000 all the way back to the year 1965, as the courts apparently are holding at the present time." $I d$. (statement of Rep. Erlenborn).

15. Humphrey v. Southwestern Portland Cement Co., 369 F. Supp. 832, 831 (W.D. Tex. 1973), rev'd on other grounds, 488 F.2d 691 (5th Cir. 1974) ("Discrimination is a vicious act. It may destroy hope and any trace of self-respect. That, and not the loss of pay, is perhaps the injury which is felt the most and the one which is the greatest.") Scc generally Seaton v. Sky Realty Co., 491 F.2d 634, 637-38 (7th Cir. 1974) (compensatory damage award upheld in $\S 1982$ action alleging racially motivated refusal to negotiate for sale of dwelling because "humiliation [can be] inferred from the circumstances or established by testimony"); Richardson v. Communications Workers of America, 443 F.2d 974, 983 (8th Cir. 1971), cert. denied, 414 U.S. 818 (1973) ("The damage arising from invidious discrimination . . . may often times be measured only in terms of the mental distress, anguish and humiliation caused."); Duda, Damages for Mental Suffering in Discrimination Cases, 15 Clev.-MAR. L. Rrv. 1 (1966). 
training. ${ }^{10}$ Although less readily quantified, these injuries are often great; the employee should be compensated for them. The lower courts, however, have generally held that compensatory damages (apart from back pay) ${ }^{17}$ are not available under Title VII. ${ }^{18}$

Finally, the elaborate administrative procedures provided by Title VII for federal employees tend to frustrate the statutory aims by impeding efforts to obtain relief. ${ }^{19}$

\section{The Section 1981 Damage Suit}

\section{A. Deterrence and Compensation}

In Johnson v. Railway Express Agency, the Supreme Court recently made clear that Title VII and $\$ 1981$ are independent remedies for

16. Humphrey v: Southwestern Portland Cement Co., 369 F. Supp. 832, 834 (W.D. Tex. 1973), rev'd on other grounds, 488 F.2d 691 (5th Cir. 1974) (loss of a job "means the loss of a sense of achievement and the loss of a chance to learn"); Ethridge v. Rhodes, 268 F. Supp. 83, 88 (S.D. Ohio 1967) ("[D]iscrimination in the area of employment stunts the educational and technical potential development of the class subject to such inequitics."); Larson, The Development of Section 1981 as a Remedy for Racial Discrimination in Privale Employment, 7 Harv. Civ. Rights-Civ. Lib. L. Rev. 56, 96 (1972).

17. Recovery of back pay could be considered as payment of compensatory damages. The courts, however, have usually characterized back pay as an integral part of the equitable remedy of reinstatement. Therefore, for the purposes of this Note, back pay is not included in the category of compensatory damages.

18. Most of the lower courts have determined that just as $\$ 706(\mathrm{~g})$ does not provide for the award of punitive damages, see note 10 supra, it atso does not provide for the award of compensatory damages. E.g., Howard v. Lockheed-Georgia Co., 372 F. Supp. 854, 856 (N.D. Ga. 1974); Van Hoomissen v. Xerox Corp., 368 F. Supp. 829, 835-38 (N.D. Cal. 1973); Attkisson v. Bridgeport Brass Co., 5 F.E.P. Cas. 919, 920 (S.D. Ind. 1972); Tooles v. Kellogg Co., 336 F. Supp. 14, 18 (D. Neb. 1972) (approving punitive damage awards in dictum, but holding compensatory damages inappropriate); Developments in the Law, supra note 9, at 1259-64 (arguing that punitive but not compensatory damages are available under Title VII). But see Rosen v. Public Serv. Elec. \& Gas Co., 477 F.2d 90, 96 (3d Cir. 1973) (male employees who retired under a discriminatory pension can receive damages to compensate them for their lost retirement benefits); Evans v. Sheraton Park Hotel, 503 F.2d 177, 179, 186 (D.C. Cir. 1974) (upholding $\$ 500$ award for harassment of the plaintiff for filing a complaint alleging sex discrimination; court suggested that the award was for back pay); Humphrey v. Southwestern Portland Cement Co., 369 F. Supp. 832, 835 (W.D. Tex. 1973), rev'd on olher grounds, 488 F.2d 691 (5th Cir. 1974) (awarding damages to compensate the plaintiff for mental distress, stating that "the purpose of the Act will best be served if all of the injuries which are caused by discrimination are entitled to recognition," and that the remedies explicitly provided by Title VII were insufficient to compensate the plaintiff for all his injuries); Goldberg, supra note 9, at 366-70, (arguing that compensatory as well as punitive damages are available under Title VII). As with punitive damages under Title VII, the Supreme Court has noted the position of the lower courts without approving or disapproving it. Johnson v. Railway Express Agency, 421 U.S. 454, $458-59$ n.5 (1975).

19. Abernathy, supra note 5 , at 325 n.10 (grievance procedures for federal employees are "a model of bureaucratic obstructionism and delay"). For a summary of the administrative procedures provided by Title VII for private and federal employees, see Note, Federal Employment Discrimination: Scope of Inquiry and the Class Action Under Tille I'II, 22 U.C.L.A. L. REv. 1288 (1975). 
private employment discrimination. ${ }^{20}$ In a suit brought under $\$ 1981$, the plaintiff may recover punitive ${ }^{21}$ and compensatory ${ }^{22}$ damages as well as unlimited back pay ${ }^{23}$-monetary relief which is not available under Title VII. The $\$ 1981$ damage remedy for private employment discrimination is a valuable supplement to Title VII; it holds a similar promise for federal employment discrimination.

There can be little doubt that the spectre of personal liability is much more likely to deter a federal official from discriminating than the threat of an injunctive order or a recovery of back pay from the federal agency. ${ }^{24}$ Moreover, as in private discrimination, a $\$ 1981$

20. 421 U.S. 454 (1975) (holding that timely filing of a Title VII employment discrimination charge with the Equal Employment Opportunity Commission (EEOC) does not toll the cunning of the limitation period applicable to an action, based on the same facts, brought under $\$ 1981$ ). The Court stated that the remedies available under $\$ 1981$ and Title VII for private employment discrimination "although related, and althougl directed to most of the same cnds, are separate, distinct, and independent." It noted that "[u]nder some circumstances, the administrative route [of Title VIl] may be highly preferred over the litigatory; under others, the reverse may be true." Id. at 461 .

21. Id. at 460 ("An individual who establishes a cause of action under $\$ 1981$ is entitled to both equitable and legal relief, including compensatory and, under certain circumstances, punitive damages.") It is difficult to draw the line between compensatory and punitive damages in employment discrimination cases and other suits involving deprivations of constitutional rights. See Goldberg, supra note 9, at 366-68. It is also unclear what standard must be met for an award of punitive damages. The general rule is that they may be imposed only if the "defendant has acted wilfully and in gross disregard for the rights of the complaining party." Lee v. Southern Home Sites Corp., 429 F.2d 290, 294 (5th Cir. 1970). But some courts have taken the view that the nature of the harm involved in deprivations of constitutional rights in and of itself warants the award of punitive damages. See, e.g., Nixon v. Herndon, 273 U.S. 536 (1927) (suit for $\$ 5000$ damages for denial of xight to vote in primary election); Wayne v. Venable, 260 F. 64, 66 (8th Cir. 1919) (\$2000 awarded each plaintiff for denial of right to vote); Fisher v. Volz, 496 F.2d 333, 346-488 n.23 (3d Cir. 1974) (punitive damages awarded for unconstitutional police search); Basista v. Weir, 340 F.2d 74, 87 (3d Cir. 1965) (\$1500 punitive damages in $\$ 1983$ suit against police officers). For a general discussion of standards for awarding damages for violations of civil rights, see Richards, Compensatory and Punitiv'e Damages in Employment Discrimination Cases, 27 ARK. L. Rev. 603 (1973); Note, Civil Actions for Damages Under the Federal Civil Rights Statutcs, 45 Tcxas L. Rev. 1015 (1967); Note, Measuring Damages for Violations of Individuals' Constitutional Rights, 8 VAL. U. L. REv. 357 (1974).

22. Compensatory damages may be granted to cover psychic injury, the loss of experience and training, and other expenses caused by the discrimination. See notes 15,16 supra; McCrary v. Runyon, 515 F.2d 1082 (4th Cir. 1975), cert. granted, 96 s. Ct. 351 (1975) (\$ 1981 action awarding damages for embarrassment, humiliation, and mental anguish to parents of black children denied admission to private school on the basis of race); Jackson v. Wheatley School Dist., 464 F.2d 411 (8th Cir. 1972) (compensatory damages granted under $\$ 1981$ for loss of earnings and other cxpenses resulting from discriminatory discharge of teacher); Lazard v. Boeing Co., 322 F. Supp. 343, 345 (E.D. La. 1971) (compensatory damages available under $\$ 1981$ for lost wages and personal humiliation). See generally Richards, supra note 21; Goldberg, supra note 9, at 360 .

23. Johnson v. Railway Express Agency, 421 U.S. 454, 460 (1975) (“'A] backpay award under $\S 1981$ is not restricted to the two years specified for backpay recovery under Title VII.")

24. See, e.g., Note, The Doctrine of Official Immunity Under The Civil Rights Acts, 68 HaRv. L. REv. 1229, 1233 (1955). 
action may increase the incentive to seek redress by providing larger recoveries $^{25}$ and by eliminating the administrative burdens which hinder recovery. ${ }^{20}$ Additional compensation might also provide the employee with a financial cushion that would allow him to quit his job and thus escape the discriminatory environment while looking for new employment.

\section{B. Section 1981 Applied to Federal Officials}

Although the Supreme Court has not explicitly recognized $\$ 1981$ as an alternative remedy for federal employment discrimination, ${ }^{27}$ a growing number of lower courts have done so. ${ }^{28}$ In the leading case

25. Although $\$ 1981$ allows for the recovery of unlimited back pay and compensatory and punitive damages, it does not necessarily provide for larger recoveries than Title VII. Unlike $\$ 1981$, Title VII specifically allows an award of attorney's fees. 42 U.S.C. $\$ 2000 \mathrm{c}-$ 5(k) (Supp. IV 1974). See Johnson v. Railway Express Agency, 421 U.S. 454, 460 (1975). In light of the Supreme Court's recent ruling on attorney's fees in Alyeska Pipeline Serv. Co. v. Wilderness Soc'y, 421 U.S. 240 (1975), attorney's fees are available in $\$ 1981$ suits only if the defendants acted in bad faith, that is, if they are "umreasonable and obdurately obstinate." Sabala v. Western Gillette, Inc., 516 F.2d 1251, 1269 (5th Cir. 1975). Sce Kirkland v: New York State Dep't of Correctional Servs., 520 F.2d 420, 430 (2d Cir. 1975). If bad faith can be proved, $\$ 1981$ would clearly provide a larger recovery than would Title V'II, since both attorney's fees and punitive damages could be recovered. If bad faith cannot be proved, attorney's fees, and probably punitive damages, would not be available. However, $\$ 1981$ may still yicld a greater recovery where the jury gives substantial awards to compensate for the stigma and psychic injury of racial discrimination, see notes 15, 22 supia, and where there is more than two years back pay at stake.

26. See p. 521 supra. The Supreme Court has granted certiorari on the question whether an employee bringing a $\$ 1981$ action in federal court against a federal agency or official must first exhaust the administrative procedures provided under $\$ 717$ of Titlc VII, 42 U.S.C. \$ 2000e-16 (Supp. IV 1974). Brown v. General Servs. Admin., 507 F.2d 1300 (2d Cir. 1974), cert. granted, 421 U.S. 987 (1975). An exhaustion requirement would impair $\$ 1981$ as a fully independent remedy for federal employment discrimination. The Supreme Court has held that prirate employees need not exhaust Title VII's administrative procedures before instituting a $\$ 1981$ action. Johnson v. Railway Express Agency, 121 U.S. $154,460-61$ (1975). There is no convincing reason to impose an exhaustion requirement on federal employees where there is none for private employees. See Penn v. Schlesinger, 490 F.2d 700 (5th Cir. 1973), rev'd, 497 F.2d 970, 971, 975 (5th Cir. 1974) (cn banc) (Tuttle, J., dissenting) ("[T]his Court should not undertake to create a barrier to the filing of a section 1981 suit against federal officials which does not exist in similar actions against either state officials or private individuals."); Brief for Petitioner at 4467, Brown v. Gencral Servs. Admin., 421 U.S. 987 (1975), granting cert. to 507 F.2d 1300 (2d Cir. 1974). But see Penn v. Schlesinger, 490 F.2d 700, 707-14 (5th Cir. 1973) (Godbold, J., dissentiug), rev'd, 497 F.2d 970, 971 (5th Cir. 1974) (en banc) (adopting Judge Gotbold's dissent per curiam); Comment, Exhanstion of Federal Administrative Remedies in Cases Under Section 1981 of the Civil Rights Act, 1974 DUnE L. REv. 408.

27. The issue is now before the Supreme Court in Brown v. General Servs. Admin., 507 F.2d 1300 (2d Cir. 1974), cert. denied, 421 U.S. 987 (1975). The Second Circuit held that $\$ 717$ of Title VII impliedly repealed all other causes of action against federal officials, and the Supreme Court granted certiorari on the question "Is jurisdiction ... conferred by statutes enacted prior to the adoption in 1972 of Section 717 of Title Vil?" Brief for Petitioner at 1, Brown v. General Servs. Admin., 421 U.S. 987 (1975), granting cert. to 507 F.2d 1300 (2d Cir. 1974).

28. These decisions rely principally on District of Columbia v. Carter, 409 U.S. 418 , 122, 432-33 (1973) (holding that $\$ 1983$ does not apply to the District of Columbia, but 
of Bowers v. Camplell, ${ }^{29}$ Judge Hufstedler reached this conclusion by the following reasoning: in District of Columbia v. Carter, the Supreme Court stated in dictum that $\$ 1982$ (the companion statute to $\S 1981)$ applies to federal as well as state action.:"0 Later that year in Tillman 7 . Wheaton-Haven Recreation Ass'n, the Court stated that because both $\$ \S 1981$ and 1982 are based on the Thirteenth Amendment and derived from the Civil Rights Act of 1866, they should be similarly construed. ${ }^{31}$ Hence $\$ 1981$ applies to the federal government, and specifically to federal employment discrimination.

A $\S 1981$ suit may be brought against a federal official in both his official and his private capacities. Some courts have ruled that $\$ 717$ of the 1972 amendments to Title VII impliedly repealed the $\$ 1981$ cause of action against an official in his official capacity. ${ }^{32}$ The basis for this position is that when Congress amended Title VII in the spring of 1972, the consensus in the lowver courts was that sovereign immunity absolutely barred $\S 1981$ suits against the federal government. ${ }^{33} \mathrm{It}$ is argued that in $\S 717$ Congress granted federal employees

noting in dictum that $\S 1982$ applies to the federal government). See Bowers v. Campbell, 505 F.2d 1155, 1157.58 (9th Cir. 1974) (relying also on Tillman v. Wheaton-Haven Recreation Ass'n, 410 U.S. 431 (1973)); Penn v. Schlesinger, 490 F.2d 700, 702-03 (5th Cir. 1973), rev'd on other grounds, 497 F.2d 970 (5th Cir. 1974) (en banc); Henry v. Schlesinger, 44 U.S.L.W. 2375 (E.D. Pa., Jan. 7, 1976); Fleming v. Simon, 397 F. Supp. 1202, 1203 (N.D. Cal. 1975) (relying on Bowers); Revis v. Laird, 391 F. Supp. 1133, 1137 (E.D. Cal. 1975) (relying on Bowers); Wright v. National Archives \& Records Serv., 388 F. Supp. 1205, 1207-08 (D. Md. 1975) (relying also on Tillman).

29. 505 F.2d 1155, 1157-58 (9th Cir. 1974) (action by federal employee seeking injunctive and declaratory relief and back pay against officers of United States air station on ground that she was removed from a trainee position, denied later promotions, harassed, and reprimanded because of her race).

30. 409 U.S. 418,422 (1973) (the Court noted that $\$ 1982$ bars all discrimination in the sale or rental of property "private as well as public, federal as well as state" (emphasis added)).

31. 410 U.S. 431, 439 (1973) (holdling that $\$ 1981$ and $\$ 1982$ should be similarly construed when applied to a claim that a community swimming pool was a private club). The basis for the holding was the "historical interrelationship" between $\S 1981$ and $\$ 1982$. Id. at $439-40$ n.11.

32. The Second Circuit is the only court of appeals that has taken this position. Brown v. General Servs. Admin., 507 F.2d 1300 (2d Cir. 1974), cert. granted, 421 U.S. 987 (1975). Some district courts have followed Brown. E.g., Cozad v. Johnson, 397 F. Supp. 1235, 1238 (W.D. Okla. 1975). In Cozad, the court distinguished both Revis v. Laird, 391 I. Supp. 1133 (E.D. Cal. 1975), and Bowers v. Campbell, 505 F.2d 1155 (9th Cir. 1974), because these suits had arisen prior to the 1972 amendments to Title VII. The Cozad court reasoned that Bowers and Revis did not involve what it called the "pure" preemption issuc-that is, whether $\$ 717$ added by the 1972 amendments preempts a claim arising after the enactment of the amendments. The court held that these post-amendment claims were preempted.

33. This consensus rested in large part on Judge (now Justice) Blackmun's decision in Gnotta v. United States, 415 F.2d 1271 (8th Cir. 1969), cert. denied, 397 U.S. 934 (1970), cited in Brown v. General Servs. Admin., 507 F.2d 1300, 1307 (2d Cir. 1974), cert. granted, 421 U.S. 987 (1975). See Wright v. National Archives \& Records Serv., 388 F. Supp. 1205, 1207 (D. Md. 1975); Abernathy, supra note 5, at 337-40. Recently, however, this consensus has croded. See note 103 infra. 
a private right of action which it believed did not previously exist, and hence that the waiver of sovereign immunity in $\$ 717$ must be strictly construed as an implied repeal of $\S 1981$ to the extent that $\$ 1981$ might reach federal employment discrimination. ${ }^{34}$

This argument is unpersuasive. Neither the language ${ }^{35}$ nor the legislative history ${ }^{36}$ of the 1972 amendments suggests that Congress intended to repeal $\S 1981$. Applying $\S 717$ in a different context, the Supreme Court recently reasserted that repeals by implication are disfavored. ${ }^{37}$ In addition, since Congress enacted $\$ 717$ to give federal employees the same rights already enjoyed by private workers, ${ }^{38}$ the

34. Brown v. General Servs. Admin., 507 F.2d 1300, 1306 (2d Cir. 1974), cert. granted, 421 U.S. 987 (1975).

35. Section $717(c)$ indicates that Congress intended not to repeal any existing statutes:

Nothing contained in this Act shall relieve any Government agency or official of

its or his primary responsibility to assure nondiscrimination in employment as required by the Constitution and stalutes or of its or his responsibilities under Executive Order 11478 relating to equal employment opportunity in the Federal Government. 42 U.S.C. $\$ 2000 \mathrm{e}-16(\mathrm{e})$ (Supp. IV 1974) (emphasis added).

36. Although Congress did take notice of the sovereign immunity issue raised in suits against federal officials, it did not indicate an intent to repeal $\$ 1981$. For instance, the report of the Senate Committee on Labor and Public Welfare noted:

The testimony of the Civil Service Commission notwithstanding, the committee found that an aggrieved Federal employee does not have access to the courts. In many cases, the employee must overcome a U.S. Government defense of sovereign immunity or failure to exhaust administrative remedies with no certainty as to the steps required to exhaust such remedies. Moreover, the remedial authority of the Commission and the courts has also been in doubt.

S. ReP. No. 92-415, 92d Cong., Ist Sess. 16 (1971).

One week before the Senate debated the extension of Title V'II to federal employment discrimination, it rejected an amendment to Title VII which would have expressly repealed $\S 1981$ as a remedy for private employment discrimination. 118 CoNG. REc. 3965 (1972). The Hruska Amendment to S. 2515 proposed to make Title VII "the exclusive remedy of any person claiming to be aggriesed by an unlawful employment practice of an employer, employment agency, or labor organization." 118 CoNG. REc. 3173 (1972). Speaking in opposition to the Hruska amendment, sereral senators emphasized the importance of the civil rights statutes as independent remedies for employment discrimination. Senator Javits made the following statement before the floor rote:

There are other remedies [than Title VII], but those other remedies are not surplusage. Those other remedies are needed to implement the promise we make under the Constitution to prevent discrimination in employment. The laws of 1866, 1871, as well as the law of 1964 , are to implement that promise.

118 CoNG. REc. 3961 (1972). In the same debate, Senator Williams quoted the 1866 Civil Rights Act, and said:

The statute I have quoted was followed up, in 1871, by another provision. These are basic laws from which, as the Attorney General stated, developed a body of law that should be preserved and not wiped out, and that all available resources should be used in the effort to correct discrimination in employment.

118 CoNG. Rec. 3964 (1972). The Senate rejected a similar amendment to Title VII in 1964. 110 CoNG. Rec. 13650-52 (1961) (Tower amendment).

37. In Morton v. Mancari, 417 U.S. 535, 549, 551 (1974), the Court held that the federal anti-discrimination provisions of $\$ 717$ did not repeal the apparently inconsistent preference for Indian employees in the Bureau of Indian Affairs under the Indian Reorganization Act of 1934. 25 U.S.C. $\$ 472$ (1970).

38. See 118 Coxg. Rec. 4922 (1972) (remarks of Sen. H.A. Williams); S. ReP. No. 92-415, 92d Cong., lst Sess. 16 (1971). 
courts should construe $\S 717$ by relying on the meaning and the construction of Title VII as applied to private employees. ${ }^{32}$ The Court's recent decision in Johnson is grounded on the proposition that Title VII did not impliedly repeal $\S 1981$ as a remedy for private employees. ${ }^{40}$ The $\$ 1981$ suit should thus be available as an alternative remedy for federal as well as private employment discrimination. In any event, even if the $\$ 1981$ action against the official in his official capacity is impliedly repealed by $\S 717$, a $\S 1981$ suit against the official in his personal capacity may still be brought. ${ }^{41}$

The efficacy of the $\$ 1981$ remedy ultimately turns on the judicial application of two distinct doctrines of governmental immunity. If a $\$ 1981$ suit for back pay and damages is brought against a private employer, the employer is the only possible source of recovery, and there is, of course, no immunity doctrine to protect him. But if a similar suit is brought against a government official, there are two sources of recovery-the government and the official in his private capacity-and each is protected by a separate immunity doctrine. When the victim of discrimination sues the official in his official capacity, the suit is directed at the government treasury, and sovereign immunity can be invoked as a defense. ${ }^{42}$ But when the victim sues the official in his private capacity, the major obstacle to recovery is executive immunity, the protector of the official's pocket.

39. Brief for Petitioner at 9, Brown v. General Servs. Admin., 421 U.S. 987 (1975), granting cert. to 507 F.2d 1300 (2d Cir. 1974).

40. Johnson v. Railway Express Agency, 421 U.S. 454, 459 (1975) (citation omitted):

Despite Title VII's range and its design as a comprehensive solution for the problem of invidious discrimination in employment, the aggrieved individual clearly is not deprived of other remedies he possesses and is not limited to Title VII in his search for relief. ... In particular, Congress noted "that the remedies available to the individual under Title VII are co-extensive with the individual's right to sue under the provisions of the Civil Rights Act of 1866, 42 U.S.C. $\$ 1981$, and that the two procedures augment each other and are not mutually exclusive."

41. Miller v. Saxbe, 396 F. Supp. 1260, 1262 (D.D.C. 1975). In Miller, Judge Gesell held that the plaintiffs' cause of action against the United States for back pay and promotion under $\$ 1981$ was preempted by Title VII, but allowed the $\$ 1981$ action for damages and injunctive relief against the individual defendants to proceed.

42. Absent a waiver, sovereign immunity bars suit against a federal officer in his official capacity if the request for relief would run against the Government's property or funds, would interfere with the public administration, or would require action by the sovereign. Dugan v. Rank, 372 U.S. 609, 620 (1963). But there are two exceptions to this rule: if the officer's actions are either beyond his statutory authority, or unconstitutional, the suit is not barred. Larson v. Domestic \& Foreign Commerce Corp., 337 U.S. 682, 701-02 (1949); Dugan v. Rank, supra at 621-22. These two cxceptions are commonly referred to as the Larson-Dugan exceptions. Under these exceptions, however, sovercign immunity may still limit the relief sought to the extent that it "will require afffirmative action by the sorereign or the disposition of unquestionably sovereign property." 


\section{Qualified Executive Immunity}

For most of the 20th century, executive officials with discretionary duties have generally enjoyed an absolute immunity from damage suits. ${ }^{43}$ The absolute immunity rule rested on two "mutually dependent rationales": it would be unfair to subject officials with discretionary duties to personal liability, and the threat of liability would deter such officials from performing their jobs effectively. ${ }^{44}$ In 1974, however, the Supreme Court cut back this immunity with its decision in Scheuer v. Rhodes, ${ }^{45}$ holding that under some circumstances high level executive officials may be personally liable for damages.

\section{A. State Officials}

In Scheuer and Wood v. Strickland,"40 the Court defined a "qualified" 47 executive immunity to be applied in civil damage suits for deprivations of constitutional rights. Both Scheuer and Wood involved civil rights actions brought under $\$ 1983$ against state officials..$^{48}$ In Scheuer, the parents of the students killed during campus demonstrations at Kent State University sued the Governor of Ohio and other high level state officials, alleging that the defendants had deprived their children of life without due process of law..$^{40}$ The Supreme Court

Larson v. Domestic \& Foreign Commerce Corp., supra at 691 n.11. For a discussion of sovereign immunity in federal cmployment discrimination suits, see Abernathy, supra note 5; Freed, Suits to Remedy Discrimination in Government Employment-The Immunity Problem, 5 Colum. Human Rights L. Rev. 383 (1973); notes 103-07 infra.

43. See, e.g., Barr v. Matteo, 360 U.S. 564 (1959); Spalding v. Vilas, 161 U.S. 483 (1896); Fidtler v. Rundle, 497 F.2d 794, 798-802 (3d Cir. 1974); Johnson v. Alldredge, 488 F.2d 820, 823-27 (3d Cir. 1973), cert. denied, 419 U.S. 882 (1974); Krause v. Rhodes, 471 F.2d 430 (6th Cir. 1972), rev'd sub nom. Scheuer v. Rhodes, 416 U.S. 232 (1974); Martone v. McKeithen, 413 F.2d 1373, 1375 (5th Cir. 1969); Norton v. McShane, 332 F.2d 855, 859-60 n.5 (5th Cir. 1964), cert. denied, 380 U.S. 981 (1965) (list of cases applying absolute immunity doctrine to suits against officials for many different torts); Francis v. Lyman, 216 F.2d 583, 588-89 (Ist Cir. 1954); Note, supra note 24, at 1229-32; Comment, Civil Liability of Subordinate State Officials L'nder the Federal Civil Rights Acts and the Doclrine of Official Immunity, 44 CAL. L. REV. 887, 891 (1956).

44. Scheuer v. Rhodes, 416 U.S. 232, $239-40$ (1974).

45. Id. For discussions of the case, see Note, Sovereign Immunity-Scheuer $v$. Rhodes: Reconciling Section 1983 Damage Actions with Government Immunities, 53 N.C.L. REv. 439 (1974); Comment, Scheuer v. Rhodes: A Restatement of Absolute Immunity, 60 IowA L. REV. I9I (1974).

46. 420 U.S. 308 (1975). The case is discussed in The Supreme Court, 1974 Term, 89

HaRv. L. Rev. 219 (1975).

47. 416 U.S. at 247 .

48. 42 U.S.C. $\$ 1983$ provides:

Every person who, under color of [state law] subjects, or causes to be subjected, any citizen of the United States ... to the deprivation of any rights, privileges, or immunities secured by the Constitution and laws, shall be liable to the party injured .....

49. 416 U.S. at 235 . The complaints alleged that the defendant officials " intentionally, recklessly, willfully and wantonly' caused an unnecessary deployment of the Ohio Na- 
reversed the holding of the court of appeals that the suit was barred by the common law doctrine of executive immunity. ${ }^{50}$ Despite the Court's extensive discussion of common law precedent, ${ }^{51}$ its decision modified the old immunity doctrine in two fundamental ways. First, the Court made an implicit distinction between torts such as defamation that are not of constitutional magnitude and deprivations of constitutional rights. Before 1974, the Court had granted public officials absolute immunity in two defamation suits, ${ }^{52}$ and some lower courts had extended absolute immunity to officials in suits alleging constitutional deprivations.53 In Scheuer, where the plaintiffs claimed denials of constitutional rights, the Court distinguished its two defamation decisions and thus failed to endorse this extension. ${ }^{54}$

Second, Scheuer moved away from the traditional "duty" analysis of immunity. Before Scheuer, the immunity question usually turned on the type of duties performed by the official. The courts categorized duties as either "ministerial" or "discretionary." 55 Because lower level

tional Guard on the Kent State campus and, in the same manner, ordered the Guard members to perform allegedly illegal actions which resulted in the deaths of [the students]." Id.

50. The district court had dismissed the actions because they were against the state and therefore barred by the Eleventh Amendment. Note, supra note 45 , at 441 n.15. The Sixth Circuit Court of Appeals affirmed, holding alternatively that an unqualified ex: ecutive immunity protected the defendants. Krause v. Rhodes, 471 F.2d 430 (6th Cir. 1972). The Supreme Court reversed the dismissals and held that the claimants were "entitled to be heard more fully than is possible on a motion to dismiss a complaint." 416 U.S. at 250.

51. 416 U.S. at 243-46. The Court reviewed the development of the common law doctrine of executive immunity and discussed its previous decisions applying common law immunity doctrines under $\$ 1983$. Pierson v. Ray, 386 U.S. 547, 554 (1967), and Tenney v. Brandhove, 341 U.S. 367 (1951), extended to $\$ 1983$ actions the absolute inmunity afforded by the common law to judicial and legislative officials. The Pierson Court also relied on common law precedent in holding that police officers were entitled to only a qualified immunity in a $\$ 1983$ action. 386 U.S. at 555. The Scheuer Court did not cite comparable common law to support its holding.

52. Barr v. Matteo, 360 U.S. 564 (1959); Spalding v. Vilas, 161 U.S. 483 (1896). In Spalding, the Court held that the Postmaster General and his fellow cabinet members enjoyed an absolute immunity in defamation suits, regardless of allegations of malicious intent. Barr extended absolute immunity to a lower federal official, the Acting Director of the Office of Rent Stabilization.

53. E.g., lower court cases cited in note 43 supra. But see Sostre v. McGinnis, 442 F.2d 178, 205 n.51 (2d Cir. 197I) (en banc); Roberts v. Williams, 456 F.2d 819 (5th Cir.), cert. denied, 414 U.S. 866 (1972); McLaughlin v. Tilendis, 398 F.2d 287 (7th Cir. 1968).

54. The Court did not expressly distinguish torts such as defamation from deprivations of constitutional rights. But it did note that if high executive officers were given an absolute immunity, "the fiat of a state Governor, and not the Constitution of the United States, would be the supreme law of the land ... . There is no such avenue of escape from the paramount authority of the Federal Constitution." " 416 U.S. at 248-49, quoting Sterling v. Constantin, 287 U.S. 378, 397 (1932). Some of the lower courts have since commented on the distinction more cxplicitly. E.g., States Marine Lines, Inc. v. Schultz, 498 F.2d 1141, 1159 n.12 (4th Cir. 1974); Burkhart v. Saxbe, 397 F. Supp. 489, 502 n.3 (E.D. Pa. 1975).

55. Mark v. Groff, 521 F.2d 1376, 1379 (9th Cir. 1975) ("Prior to Scheuer, exccutive officers were granted absolute immunity from damage suits if they were acting within 
executive officials such as police officers were said to exercise ministerial duties, they enjoyed only the limited protection of qualified immunity. ${ }^{56}$ But higher level officials, to the extent they exercised discretion, were cloaked with absolute immunity no matter what they did. ${ }^{57}$ Judicial attempts to resolve the immunity claims of officials with duties falling somewhere between these two poles pointed up the inadequacy of this rigid classification. ${ }^{58}$

Although the Scheuer test considers the type of duties exercised by the defendant official, it does not turn on the ministerial-discretionary distinction. Rather, if a deprivation of a constitutional right is alleged, the official, no matter what his duties, does not enjoy absolute protection from a damage suit. Scheuer states two requirements for immunity: the official must have a good faith belief in the constitutionality of his conduct, and his belief must be reasonable, considered in light of all the circumstances as they appeared at the time of the alleged harm. ${ }^{50}$ Although good faith belief is a subjective factor, the companion "reasonableness of belief" standard injects an objective component into the immunity test.

There is a critical factual difference between Scheuer and Wood $v$.

the outer perimeter of their scope of authority and were performing a discretionary as opposed to a ministerial act."); Estate of Burks v. Ross, 438 F.2d 230, 235 (6th Cir. 1971); Jaffe, Suits Against Government and Officers: Damage Actions, 77 Harv. L. Rev. 209, 219 (1963) (discussing the inadequacy of this approach).

56. See, c.g., Carter v. Carlson, 447 F.2d 358 (D.C. Cir. 1971), rev'd in part on other grounds sub nom. District of Columbia v. Carter, 409 U.S. 418 (1973) (Bazelon, J.) (arresting officer not protected by absolute immunity in $\S 1983$ suit because his act was ministerial rather than discretionary); Bivens v. Six Unknown Named Agents of the FBI, 456 F.2d 1339 (2d Cir. 1972) (on remand from the Supreme Court). As Judge Medina cxplained in Bivens, it is clearly a "fiction" to say that a police officer does not exercise discretion in making an arrest. The fiction is maintained, he said, "because of the belief that the benefit to society derived from the protection of personal liberties outweighs the detriment of perhaps deterring vigorous police action." Id. at 1346 .

57. See cases and articles cited in note 43 supra.

58. Compare, e.g., Sostre v. Rockefeller, 312 F. Supp. 863 (1970), rev'd, aff'd \& modified in part sub nom. Sostre v. McGinnis, 442 F.2d 178 (2d Cir. 1971) (state prison warden held liable for constitutional deprivation), and Jobson v. Henne, 355 F.2d 129, 134 \& n.11 (2d Cir. 1966) (director of state mental hospital found liable for constitutional deprivation), wilh Fidtler v. Rundle, 497 F.2d 794 (3d Cir. 1974) (state prison warden immune if his duties were discretionary), and Johnson v. Alldredge, 488 F.2d 820 (3d Cir. 1973) (federal prison warden absolutely immune from damage suits for alleged deprivations-of constitutional rights).

59. The Court stated the test as follows:

These considerations suggest that, in varying scope, a qualified immunity is available to officers of the executive branch of government, the variation being dependent upon the scope of discretion and responsibilities of the office and all the circumstances as they reasonably appeared at the time of the action on which liability is sought to be based. It is the existence of reasonable grounds for the belief formed at the time and in light of all the circumstances, coupled with good-faith belief, that affords a basis for qualified immunity of cxecutive officers for acts performed in the course of official conduct.

416 U.S. at 247-48. 
Strickland. ${ }^{00}$ In Wood, school board members volunteering their time to serve the community ${ }^{61}$ were sued by high school students who claimed they had been expelled without due process; ${ }^{62}$ the school officials were not full-time, paid government employees. Reaffirming the standard of liability announced in Scheuer, the Court held

that a school board member is not immune from liability for damages under $\S 1983$ if he knew or reasonably should have known that the action he took within his sphere of official responsibility would violate the constitutional rights of the student affected, or if he took the action with the malicious intention to cause a deprivation of constitutional rights or other injury to the student. ${ }^{63}$

Writing for the majority, Justice White stated that under the objective component of the test a voluntary school board member is liable if he violates a student's constitutional rights in "ignorance or disregard of settled, indisputable law"; the official is held to a standard of conduct based on "knowledge of the basic, unquestioned constitutional rights of his charges." 64

The Court did not make clear what it meant by "settled, indisputable law." ${ }^{65}$ It has been suggested that this standard affords all types of government officials broad immunity and that only an authoritative decision by the Supreme Court would be sufficient to meet the standard. ${ }^{66}$ Yet post-Wood case law indicates that this analysis

60. 420 U.S. $308(1975)$.

61. See id. at 320 n.11, 322 .

62. The students were expelled for violating a school regulation prohibiting the use or possession of intoxicating beverages at school. The district court directed a verdict for the defendants, ruling that officials cannot be held liable in damages for mistakes of law unless malice is proven. Strickland v. Inlow, 348 F. Supp. 244, 248 (W.D. Ark. 1972). The court of appeals reversed the directed verdicts for the school board members, rejecting the district court's "subjective" test in favor of an "objective" test of good faith, but affirmed directed verdicts for school officials other than school board members. Strickland v. Inlow, 485 F.2d 186, 191 (8th Cir. 1973). Both of the lower court rulings were made before Scheuer announced both "objective" and "subjective" requirements for executive immunity.

63. 420 U.S. at 322 .

64. Id. at 321,322 .

65. Concurring in part and dissenting in part, Justice Powell (joined by Chief Justice Burger and Justices Blackmun and Rehnquist) pressed this point: "One need only look to the decisions of this Court ... to recognize the hazard of even informed prophecy as to what are "unquestioned constitutional rights." Justice Powell endorsed the Scheuer test, which he viewed as a "considerably less demanding standard of liability." Id. at 330 . However, because "settled law" may mean an authoritative Supreme Court decision, the Wood test has, if anything, provided officials with more protection from liability than the Scheuer standard. The Supreme Court, 1974 Term, supra note 46, at 224-25 \& nn.40, 41, quoted in note 66 infra.

66. The Supreme Court, 1974 Term, supra note 46, at 224-25 (footnote omitted):

$[P]$ rior to an authoritative Supreme Court decision on an issue, disagreements among 
paints too broad a stroke. Although the "settled law" standard may require nothing less than a Supreme Court decision, it has been applied primarily to volunteer school board members. ${ }^{67}$ When paid government officials are involved, a more general test of reasonableness has been consulted to determine liability. ${ }^{68}$ In its latest application of the doctrine of qualified executive immunity, a unanimous Supreme Court adopted this approach, consulting both Schener and Wood in considering the liability of a paid state official. ${ }^{69}$ Under the Scheuer-Wood standard, even if a judge finds that the law is not

courts, or perhaps even among commentators, about the applicable law should be sufficient to bar liability. ... Wood actually restricts significantly the number of instances in which officials can be held liable for mistakes of law, without foreclosing altogether the possibility of such liability.

Compare Picha v. Wielgos, 44 U.S.L.W. 2434 (N.D. Ill., Mar. 4, 1976) (law may be settled without there having been a specific case with identical facts; relying on decision of another district court to settle Fourth Amendment protection required for student searched by school official with police involvement).

67. E.g., Bertot v. School Dist. No. I, 522 F.2d 1171, 1184-85 (10th Cir. 1975); Shirley v. Chagrin Falls Exempted Village Schools Bd. of Educ., 521 F.2d 1329, 1331-32 (6th Cir. 1975); Hutchinson v. Lake Oswego School Dist. No. 7, 519 F.2d 961, 968 (9th Cir. 1975) ("the courts themselves have been split" on constitutional issue involved); Zeller v. Donegal School Dist. Bd. of Educ., 517 F.2d 600, 609 (3d Cir. 1975) (en banc) (Rosenn, J., concurring and dissenting) (division among circuits and absence of Supreme Court opinion makes law unsettled); Sapp v. Renfroe, 511 F.2d 172, 178 (5th Cir. 1975) (law unsettled because of absence of decisions by Supreme Court and Fifth Circuit).

68. O'Connor v. Donaldson, 422 U.S. 563 (1975) (superintendent of a state mental hospital); Paton v. La Prade, 524 F.2d 862, 872 (3d Cir. 1975) (FBI officials alleged to have violated the constitutional rights of high school students and teacher); Laverne v. Corning, 522 F.2d 1144, 1147-50 (2d Cir. 1975) (inspections by village officials); Mark v. Groff, 521 F.2d 1376, 1380-81 (9th Cir. 1975) (cmphasis on Scheuer in suit brought by tax accountant alleging violation of constitutional rights by IRS agents); Jones v. Diamond, 519 F.2d 1090, 1101 (5th Cir. 1975) (members of county board of supervisors and others); Bryan v. Jones, 519 F.2d 44, 46 (5th Cir. 1975) (sheriff found by jury to have falsely imprisoned plaintiff); Schiff v. Williams, 519 F.2d 257, 261 (5th Cir. 1975) (university president violated First Amendment rights of editors of student newspaper); Glasson v. City of Louisville, 518 F.2d 899, 910.11 (6th Cir. 1975) (policemen violated plaintiff's First Amendment rights); Thonen v. Jenkins, 517 F.2d 3, 5.6 (4th Cir. 1975) (students disciplined by university president because of letter published in school newspaper).

69. O'Connor v. Donaldson, 422 U.S. 563 (1975). Donaldson alleged that O'Connor, the superintendent of a Florida state mental hospital, and other staff members had intentionally and maliciously deprived him of his constitutional right to liberty. The jury found for Donaldson and awarded $\$ 28,000$ in compensatory damages and $\$ 10,000$ in punitive damages. The court of appeals affirmed. 493 F.2d 507 (5th Cir. 1974). But the court of appeals did not consider whether the trial judge erred in refusing to instruct the jury that $O^{\prime}$ Connor was not liable if he had relied on state law not yet declared unconstitutional. The Supreme Court remanded for a determination of this narrow question in light of the immunity test stated in Wood. 422 U.S. at 577, on remand, 519 F.2d 59 (5th Cir. 1975) (reconsidered only in light of Wood). Although the Court made only passing reference to Scheuer, it made no reference to the more protective "settled law" standard applied to the school board members in Wood.

In Imbler v. Pachtman, 44 U.S.L.W. 4250,4253 n.13 (U.S. Mar. 2, 1976) (prosecutor given absolute immunity in $\$ 1983$ action), the Court briefly discussed qualified executive immunity. Citing both Scheuer and Wood, it noted that " $[\mathrm{t}]$ he fate of an official with qualified immunity depends upon the circumstances and motivations of his actions, as established by the evidence at trial." 
fully "settled," a jury may still determine that the official "reasonably should have known" that the action he took would violate constitutional rights. ${ }^{70}$ Reasonableness is determined in large part by the type of duties performed by the official, a factor that cuts two ways. Because higher level officials exercise discretion, they may be entitled to more immunity. ${ }^{71}$ But because of their increased responsibilities, they also have a greater duty to know the law, a consideration that militates against immunity.

The distinction between voluntary and paid officials makes sense. In Wood, both the majority and minority emphasized that if citizens are not to be deterred from serving the community as volunteer school board members, they must be given more protection from liability than regular government officials. ${ }^{72}$ This reasoning applies with equal force to other volunteer officials. Some courts, however, have ignored the rationale of Wood and shielded nonvolunteer officials with the more protective "settled" law standard. . $^{3}$

\section{B. Federal Officials}

The lower courts have also applied the Scheuer-Wood standard to federal officials, including cabinet members. ${ }^{74}$ Since $\S 1983$ makes

70. The "settled law" and "reasonableness" standards will often, but not always, produce different results. See Shirley v. Chagrin Falls Exempted Village Schools Bd. of Educ., 521 F.2d 1329, 1331 (6th Cir. 1975). In that case, the district judge found liability under Scheuer; the Wood decision intervened, and the court of appeals reversed the district judge, applying the "settled law" standard to school board officials.

71. Most courts have emphasized that the less discretion an official has, the less immunity is warranted. E.g., Mark v. Groff, 521 F.2d 1376, 1380-81 (9th Cir. 1975).

72. The majority noted that " $[t]$ he most capable candidates for school board positions might be deterred from seeking office if heavy burdens upon their private resources from monetary liability were a likely prospect during their tenure." 420 U.S. at 320 ; see id. at nn.11 \& 12. Justice Powell concluded his dissent with this observation:

In view of today's decision significantly enhancing the possibility of personal liability, one must wonder whether qualified persons will continue in the desired numbers to volunteer for service in public education.

Id. at 331 .

73. See, e.g., Zeller v. Donegal School Dist. Bd. of Educ., 517 F.2d 600 (3d Cir. 1975) (school superintendent, principal, athletic director and soccer coach); Bertot v. School Dist. No. 1, 522 F.2d 1171, 1184-85 (10th Cir. 1975) (superintendent and principal); Knell v. Bensinger, 522 F.2d 720 (7th Cir. 1975) (director of state department of corrections); Picha v. Wielgos, 44 U.S.L.TV. 2434 (N.D. Ill., Mar. 4, 1976) (school principal, nurse, and psychologist). But see cases cited in note 68 supra; Zeller v. Donegal School Dist. Bd. of Educ., supra at 612-13 (Seitz, J., dissenting). Judge Seitz noted that Wood

intimates nothing with respect to the immunity or good faith defense of officials such as a school superintendent, principal, athletic director or soccer coach .... Certainly the individual defendants here are cloaked with different types of authority and are charged with performing different acts ....

Citing Scheuer, he suggested that a reasonableness standard was appropriate for school officials other than school board members.

74. Paton v. La Prade, 524 F.2d 862 (3d Cir. 1975) (FBI agents); Mark v. Groff, 521 F.2d 1376 (9th Cir. 1975) (IRS agents); Apton v. Wilson, 506 F.2d 83 (D.C. Cir. 1974) 
only state officials liable for deprivations of constitutional rights, suits against federal officers have relied on other statutory and common law remedies. ${ }^{75}$ However, the doctrine of qualified executive immunity applies whether or not the suit is brought under $\S 1983$, as long as a state or federal official is alleged to have deprived the plaintiff of a constitutional right.

\section{The Section 1981 Remedy for Federal Employment Discrimination}

Federal employment discrimination on the basis of race is a deprivation of constitutional rights. In suits brought against the states under $\$ \S 1981$ and 1983 , the courts have held that racial discrimination in employment violates the equal protection clause of the Fourteenth Amendment. ${ }^{76}$ In Bolling $v$. Sharpe, ${ }^{77}$ the Supreme Court determined that racial discrimination which would violate the equal protection clause of the Fourteenth Amendment if practiced by a state violates the due process clause of the Fifth Amendment if practiced by the federal government. Therefore, federal employment discrimination

(Attorney General of the United States, the Deputy Attorney General, and the Chief of Police of the District of Columbia); Rowley v. McMillan, 502 F.2d 1326 (4th Cir. 1974) (Director of Secret Service and other Secret Service agents); States Marine Lines, Inc. v. Schultz, 498 F.2d 1146 (4th Cir. 1974) (Secretary of the Treasury and agents of the United States Bureau of Customs); Burkhart v. Saxbe, 397 F. Supp. 499 (E.D. Pa. 1975) (Attorncy General of the United States and Director of the FBI); Fleming v. Simon, 397 F. Supp. 1202 (N.D. Cal. 1975) (Secretary of the Treasury and others); Miller v. Saxbe, 396 F. Supp. 1260 (D.D.C. 1975) (Attorney General and others); Revis v. Laird, 391 F. Supp. 1133 (E.D. Cal. 1975) (Secretary of Defense, Sccretary of the Air Force, Commander, Vice-Commander and Deputy Commander of Mrclellan Air Force Base, Chief of the Equal Employment Opportunity Office and others); Black v. United States, 388 F. Supp. S05 (E.D.N.Y. 1975) (Sccretary of the Treasury, Commissioner of IRS, and District Director of IRS).

75. Statutory remedies include 42 U.S.C. $\$ \$ 1981,1982(1970)$. For discussion of these statutes, see notes 7, 30 supra. In Bivens v. Six Unknown Named Agents of the FBI, 403 U.S. 388 (1971), the Court established a federal common law right to sue for damages for violations of Fourth Amendment rights. The lower courts have generally held both First and Fifth Amendment claims cognizable under the Bivens rationale. Paton v. La Prade, 524 F.2d 862 (3d Cir. 1975) (First Amendment); Mark v. Groff, 521 F.2d 1376 (9th Cir. 1975) (Fifth, Sixth and Eighth Amendments); Apton v. Wilson, 506 F.2d 83 (D.C. Cir. 1974) (Fourth and Fifth Amendments); Rowley v. McMillan, 502 F.2d 1326 (4th Cir. 1974) (First and Fifth Amendments); States Marine Lines, Inc. v. Schultz, 498 F.2d 1146 (4th Cir. 1974) (Fifth Amendment); Moore v. Koelzer, 457 F.2d 892 (3d Cir. 1972) (Fifth Amendment); Revis $r$. Laird, 391 F. Supp. 1133 (E.D. Cal. 1975) (First and Fifth Amendments); Black v. United States, 388 F. Supp. 805 (E.D.N.Y. 1975) (Fifth Amendment); Butler v. United States, 365 F. Supp. 1035 (D. Hawaii 1973) (First and Fifth Amendments).

76. E.g., Afro Am. Patrolmen's League v. Duck, 503 F.2d 294, 301 (6th Cir. 1974); Bridgeport Guardians, Inc. v. Civil Serv. Comm'n, 482 F.2d 1333, 1337 (2d Cir. 1973), cert. denicd, 421 U.S. 991 (1975); Castro v. Beecher, 459 F.2d 725, 733 (Ist Cir. 1972); Chance v. Board of Examincrs, 458 F.2d 1167, 1176-77 (2d Cir. 1972); Carter v. Gallagher, 452 F.2d 315, 325 (8th Cir. 1971), cert. denied, 406 U.S. 950 (1972). 
challenged in $\S 1981$ suits deprives plaintiffs of Fifth Amendment rights. ${ }^{i s}$ The standards used by courts under $\S 1981$ to define state and federal employment discrimination are those used in employment discrimination cases under Title VII. ${ }^{79}$

\section{A. Executive Immunity and Personal Liability of Federal Officials}

Two district courts have considered claims of executive immunity by federal officials charged with racial discrimination in employment. ${ }^{80}$ Assuming that the defendant officials are responsible for the conduct challenged as discriminatory, ${ }^{81}$ liability should be found under Scheuer and Wood in either of two instances: if the official acted in bad faith, or if his belief in the constitutionality of his conduct was unreasonable. ${ }^{82}$ Bad faith is particularly hard to prove in employment discrimination cases because the discriminatory practices are often facially neutral. ${ }^{83}$ Liability is easier to establish under the "reasonable belief" standard. A finding that a federal official has

77. 347 U.S. 497 (1954) (public school segregation in the District of Columbia).

78. E.g., Miller v. Saxbe, 403 F. Supp. 1314, 1316 (D.D.C. 1975) (\$ 1981 federal cmployment discrimination suit in which Judge Gesell refused to grant summary judgment for defendants, noting that federal officials must "confine their actions to conduct consistent with elementary constitutional standards, particularly where issues of race are involved").

79. See cases cited in note 76 supra. "No court has distinguished the standard mandated by the Fifth and Fourteenth Amendments from that specified by Title VII of the Civil Rights Act of 1964." Douglas v. Hampton, 512 F.2d 976, 981 (D.C. Cir. 1975); Davis v. Washington, 512 F.2d 956, 957 n.2 (D.C. Cir.), cert. granted, 96 S. Ct. 33 (1975), Under Title VII, facially neutral tests, practices, or procedures that have a disproportionate impact on blacks must be shown to have a "demonstrable relationship" to successful job performance, p. 535 infra. The lower courts have recognized that the Title VII "demonstrable relationship" standard may require the state or federal employer to make a stronger showing than the Fourteenth Amendment "rational relationship" test, but have uniformly applied the Title VII standard in suits under $\$ \$ 1981$ and 1983 alleging constitutional violations. The Supreme Court may decide this issuc in Davis.

80. Miller v. Saxbe, 396 F. Supp. 1260, 403 F. Supp. 1314 (D.D.C. 1975) (\$ 1981 suit brought by two black United States deputy marshals charging racial discrimination in federal employment; court held that Scheuer-IWood test for executive immunity would apply); Revis v. Laird, 391 F. Supp. 1133 (E.D. Cal. 1975) (\$ 1981 suit alleging racial discrimination in employment at McClellan Air Force Base in California; court confused sovereign and executive immunity). For a discussion of these cases, see note 108 infra.

81. For two cases in which legal responsibility either was not or might not have bcen found, see Apton v. Wilson, 506 F.2d 83, $94-95$ n.13 (D.C. Cir. 1974) (Justice Department defendants asserted on appeal that the record contained no evidence of their participation in or direction of the law enforcement activities of which plaintiffs complained); Miller v. Saxbe, 403 F. Supp. 1314, 1316 (D.D.C. 1975) (motion for summary judgment granted for one defendant, a U.S. Marshal, because "he is not shown to have ordered or to have had responsibility for any of the specific alleged acts constituting the underlying basis for the complaint').

82. See pp. 527-32 supra.

83. H.R. Rep. No. 92-238, 92d Cong., lst Sess. 8 (1971); Cooper \& Sobol, Seniority and Testing Under Fair Employment Laws: A General Approach to Objective Criteria of Hiring and Promotion, 82 HAkv. L. Rrv. 1598, 1670 (1969). 
violated "settled" employment discrimination law should be sufficient to establish that an official's belief in the constitutionality of his conduct was unreasonable. Since federal employment discrimination suits are brought against paid rather than voluntary officials, however, such a showing should not be necessary to establish liability. ${ }^{84}$

Recent Supreme Court decisions have "settled" the basic Title VII principles which apply in $\$ 1981$ actions. ${ }^{85}$ Purportedly neutral "practices, procedures, or tests" which have a substantially disproportionate impact on blacks must be shown to have a "demonstrable relationship" to successful job performance. ${ }^{s 0}$ Even if such a relationship is established, the complainant may still demonstrate that "other tests or selection devices without a similarly undesirable racial effect" were available, and that the employer has therefore used the tests merely as a "pretext" for discrimination. ${ }^{\mathrm{st}}$

These principles have now been applied under both Title VII and $\$ 1981$ to testing ${ }^{\$ s}$ and seniority ${ }^{89}$ practices affecting hiring and promotion decisions. ${ }^{90}$ Findings of discrimination under these constitutional standards should be sufficient to support a conclusion that the official had no reasonable basis for a belief in the constitutionality of his conduct. And even if the unconstitutionality of his conduct were not "settled" at the time of the discrimination, a jury may still find that

84. See pp. 531-32 supra.

85. Albemarle Paper Co. v. Moody, 422 U.S. 405 (1975); Alexander v. Gardner-Denver Co., 415 U.S. 36 (1973); McDonnell Douglas Corp. v. Green, 411 U.S. 792 (1973); Griggs v. Duke Power Co., 401 U.S. 424 (1971).

86. Griggs v. Duke Power Co., 401 U.S. 424, $430-31$ (1971). In Griggs the Court focused on the job-relatedness requirements set forth in the Equal Employment Opportunity Commission (EEOC) regulations, 29 C.F.R. $\$ 1607$ (1975), promulgated to implement Title VII. The Court noted that "[t]he touchstone is business necessity" and that "good intent or absence of discriminatory intent does not redeem employment procedures or testing mechanisms that operate as 'built-in headwinds' for minority groups and are unrelated to measuring job capability." 401 U.S. at 431-32.

The lower courts have determined that there is no substantive difference between the EEOC guidelines as construed in Griggs and the yet to be interpreted Civil Service Commission guidelines for federal employment practices, 5 C.F.R. $\$ \S 300.102,300.103$ (1974). The "demonstrable relationship" standard applies to federal as well as private employment discrimination. Douglas v. Hampton, 512 F.2d 976, 989 (D.C. Cir. 1975); Davis v. Washington, 512 F.2d 956, 961-62 n.37 (D.C. Cir.), cert. granted, 96 S. Ct. 33 (1975).

87. Albemarle Paper Co. v. Moody, 422 U.S. 405, 425 (1975) (dictum); accord, McDonnell Douglas Corp. v. Green, 411 U.S. 792, 801, 804-05 (1973).

88. E.g., Albemarle Paper Co. v. Moody, 422 U.S. 405 (1975) (Title VII); Kirkland v. New York State Dep't of Correctional Servs., 520 F.2d 420, 426 (2d Cir. 1975) (\$ 1981 and $\$ 1983)$.

89. E.g., Sabala v. Western Gilette, Inc., 516 F.2d 1251 (5th Cir. 1975) (\$ 1981); United States v. Jacksonville Terminal Co., 451 F.2d 418 (5th Cir. 197I), cert. denied, 406 U.S. 906 (1972) (Title VII).

90. There are, of course, areas of Title VII litigation in which the law is less settled. Sce, e.g., Note, Last Hired, First Fired Layoffs and Tille I'II, 88 Harv. L. Rev. 1544 $(1975)$. 
his belief was unreasonable in light of all the circumstances. The type of duties exercised by the federal official would of course be important for such a determination. For instance, although the Director of the Civil Service Commission might be held liable for the use of standardized tests that violate clearly established principles of employment discrimination, ${ }^{91}$ the Secretary of Defense might not be held liable for discrimination at a particular military base. ${ }^{92}$

Once liability is determined, back pay and punitive and compensatory damages may be assessed against the official in his individual capacity. Although immunity from damages does not ordinarily bar equitable relief, ${ }^{93}$ and back pay is viewed as an integral part of the equitable relief of reinstatement, ${ }^{94}$ a back pay award, like damages, is a payment of money by the official. Hence it should be granted only if the court finds that the official is not protected by executive immunity.95

The personal liability of federal officials in $\$ 1981$ damage suits may lead Congress to enact an indemnification statute. ${ }^{90}$ Any provision for indemnification will necessarily reduce the deterrent effect of subjecting officials to personal liability. So long as indemnification is partial and discretionary, however, the deterrent effect of $\$ 1981$

91. See Douglas v. Hampton, 512 F.2d 976 (D.C. Cir. 1975) (suit against Chairman of Civil Service Commission challenging use of federal service entrance examination in hiring and promotion of federal employees).

92. See Revis v. Laird, 391 F. Supp. 1133 (E.D. Cal. 1975) (suit against Secretary of Defense and others alleging racial discrimination in employment at McClellan Air Force Base in California).

93. Wood v. Strickland, 420 U.S. 308, $314-15$ n.6 (1975). Several lower courts have granted equitable relief on the grounds that the policy considerations supporting immunity from damages do not apply to immunity from equitable relief. E.g., Boyd v. Adams, 513 F.2d 83, 86-87 (7th Cir. 1975) (barring damage recovery); Rowley v. McMillan, 502 F.2d 1326, 1331-32 (4th Cir. 1974); Supreme Court, 1974 Term, supra note 46, at 220 n.4.

94. Albemarle Paper Co. v. Moody, 422 U.S. 405, 416 (1975); Stamps v. Detroit Edison Co., 515 F.2d 301, 308 (6th Cir. 1975); United States v. Georgia Power Co., 474 F.2d 906, 921 (5th Cir. 1973) (Title VII suit); Harkless v. Sweeny Independent School Dist., 427 F.2d 319,324 (5th Cir. 1970) (\$ 1983 suit).

95. The Scheuer-Wood standard for qualified immunity in $\$ 1981$ suits against officials in their individual capacities is consistent with the Supreme Court's holding that a finding of bad faith is not necessary for an award of back pay under Title VII. Albemarle Paper Co. v. Moody, 422 U.S. 405, 413-25 (1975). The Court, however, did not announce standards necessary or sufficient for such Title VII awards.

96. At present, there is no federal statute that indemnifies federal officials for cmployment discrimination. One reason for this may be that until the Supreme Court decided Scheuer v. Rhodes, 416 U.S. 232 (1974), many federal officials enjoyed an absolute immunity from damage suits. Since the doctrine of qualified executive immunity is so new, it is difficult to assess the need for indemnification. State and local governments have protected some officials by enacting such statutes or purchasing insurance. Sce, $\varepsilon$.g., ILL. REv. STAT. ch. 122 \$ 34-18.1 (1975) (school district employees indemnificd against suits for negligence or violations of civil rights). 
actions could be preserved. ${ }^{97}$ The Government would base its decision to indemnify on its own determination of good faith and reasonableness, making awards with a conscious effort to preserve the penalty for discrimination. Even if the Government finds that the official acted either unreasonably or in bad faith, it might pay part of the judgment to assure that the victim of discrimination is quickly and fully compensated.

The need for indemnification will be considerably reduced if juries finding liability under the Scheuer-Wood test refuse to make sizeable awards of back pay and damages. ${ }^{98}$ Juries are always free to deny punitive damages, ${ }^{93}$ and in employment discrimination cases they have considerable flexibility in deciding how much the victim should be compensated for the "stigma" of discrimination-intangible injuries such as humiliation and mental anguish. ${ }^{100}$ Consequently, victims of discrimination should try to tap the Government's pocket as well as the official's.

\section{B. Sovereign Immunity and Recovery from the Government}

Simultaneously with a $\$ 1981$ suit against the official in his personal capacity, a suit to recover back pay from the Government may be brought under either Title VII or $\$ 1981$. Title VII expressly waives sovereign immunity and authorizes recovery of up to two years back pay. However, it does not allow damage awards and requires the litigant to exhaust a cumbersome administrative process or wait 180 days before suing in federal district court. ${ }^{101}$

In a $\$ 1981$ suit against the official in his official capacity, back pay recovery is not limited to two years, and exhaustion may not be re-

97. Jaffe, supra note 55, at 216-17, 229-30.

98. In a class action suit the potential personal liability of an official could be enormous. Fear that juries would not make large awards against public officials may cxplain why plaintiffs lave so far refrained from pressing class action damage suits against officials in their personal capacities.

99. E.g., Lee v. Southern Homes Sites Corp., 429 F.2d 290, 294 (5th Cir. 1970).

100. Sec note 21 supra.

101. See 42 U.S.C. $\$ \$ 2000 \mathrm{e}-5(\mathrm{f})$, (g), 2000e-16(d) (Supp. IV 1974); notes 10, 18, 19 supra. To date, only one action has been brought claiming back pay from the Government under 'Title VII and back pay and damages from the official under $\$ 1981$. Fleming v. Simon, 397 F. Supp. 1202, 1204 (N.D. Cal. 1975) (court denied defendants' motion for a protective order). The court recognized that it faced a novel situation:

What procedures the district court is to follow in getting the issues in a case such as this tried and determined will have to be sorted out as the case moves along; no appellate court has given practical guidelines for proceeding simultancously with a Title VII claim and a $\$ 1981$ claim.

The court did not suggest what such guidelines might be, nor how liability might be apportioned between the Government and the official. 
quired. ${ }^{102}$ Sovereign immunity, however, may pose a serious problem. A growing number of lower courts now recognize that sovereign immunity does not bar $\$ 1981$ suits alleging racial discrimination in employment. ${ }^{103}$ It may, however, limit the relief which the court may grant. ${ }^{104}$ Unless the Government has consented to be sued, sovereign immunity absolutely bars a damage award paid by the Government. ${ }^{105}$ It is unclear whether sovereign immunity also prevents a back pay award against the Government as part of the equitable remedy of reinstatement. Although no court has yet made such an award, it can be argued that back pay should be included with other forms of equitable relief permitted under the sovereign immunity doctrine. ${ }^{106}$ In addition, the Fifth Circuit has suggested a mandamus route around

102. See notes 23,25 supra.

103. Prior to 1972, most courts followed Judge (now Justice) Blackmun's ruling in Gnotta v. United States, 415 F.2d 1271, 1277 (8th Cir. 1969), cert. denied, 397 U.S. 934 (1970), that sovereign immunity absolutely bars federal employment discrimination suits. See Abernathy, supra note 5, at 337-40. However, shortly after the 1972 amendments to Title VII were enacted, the Fifth Circuit began to retreat from the Gnotta position. Id. at 341-44. Other courts have agreed with the Fifth Circuit that sovereign immunity is not an absolute bar to a $\$ 1981$ claim of federal employment discrimination. Bowers $v$. Campbell, 505 F.2d 1155 (9th Cir. 1974); Henry v. Schlesinger, 44 U.S.L.W. 2375 (E.D. Pa. Jan. 7, 1976); Jones v. Brennan, 401 F. Supp. 622 (N.D. Ga. 1975); Revis v. Laird, 391 F. Supp. 1133 (E.D. Cal. 1975); Wright v. National Archives \& Records Serv., 388 F. Supp. 1205, 1209 (D. Md. 1975); Abernathy, supra note 5, at 341-45. But see Baca v. Butz, 394 F. Supp. 888 (D. N.M. 1975); Archuleta v. Callaway, 385 F. Supp. 384 (D. Colo. 1974); Willingham v. Lynn, 381 F. Supp. 1119 (E.D. Mich. 1974).

104. Bowers v. Campbell, 505 F.2d 1155, 1158 (9th Cir. 1974); Abernathy, supra note 5 , at $341-43,345$ ("the courts are searching for standards to define what role sovereign immunity should play in determining relief for plaintiffs who are successful in establishing federal employment discrimination"); Freed, supra note 42 , at 407 .

105. See Dugan v. Rank, 372 U.S. 609, 620 (1963). It has been suggested that $\$ 1981$ may constitute a congressional waiver of sovereign immunity and thereby allow both back pay and damages to be collected from the federal treasury. 41 GEo. WAsh. L.J. 657, 663-64 (1973). But see Penn v. Schlesinger, 490 F.2d 700, 703 (1973), rev'd on other grounds, 497 F.2d 970 (1974) (en banc).

106. Freed, supra note 42 , at 401 , asserts that "a distinction between awards of back pay and attorneys' fees on the one hand, and other equitable relief on the other, cannot be sustained." He points out that equitable relief ordered against the Government has "frequently required expenditures from the public treasury." Id. at 398 . This view that back pay should be treated as a form of equitable relief for purposes of sovercign im. munity may seem inconsistent with the position taken at p. 536 supra that back pay should be treated as damages for purposes of executive immunity. However, there is a reason not to distinguish between back pay and other equitable relicf when they are ordered against the Government, but to distinguish between them when they are ordered against the official: equitable relief other than back pay requires expenditures by the Government, but not the official.

For another argument that sovereign immunity does not bar back pay awards against the Government, see Abernathy, supra note 5 (concluding from a separation-of-powers analysis that court orders granting reinstatement with back pay do not unduly impinge on Congress's duty to regulate the public fisc, but rather help to enforce a statcd nondiscrimination policy given high priority by both the legislative and executive branches). 
sovereign immunity that may allow for the recovery of back pay from the Government. ${ }^{107}$ Should the courts eliminate the sovereign immunity obstacle to back pay awards against the Government, the $\$ 1981$ suit against the official both in his personal and in his official capacity ${ }^{108}$ would provide an even more potent weapon to combat federal employment discrimination than the combination presently available -a \$ 1981 claim against the official coupled with a Title VII claim against the Government.

Either combination, however, provides the victim of discrimination with access to the pockets of both the Government and the official. The courts have yet to resolve the difficult question of how to apportion liability between the Government and the official in order to further the Title VII goals of deterrence and compensation. One approach would be to assess back pay against the Government and damages against the official. ${ }^{109}$ Such an apportionment might reduce

107. In Beale v. Blount, 461 F.2d 1133, $1137-38$ (5th Cir. 1972), the Fifth Circuit reasoned that although sovereign immunity barred the plaintiff's request for injunctive relief, the sovereign immunity obstacle could be bypassed by viewing the prayer for reinstatement with back pay as "an action in the nature of a petition for writ of mandamus." Id. at 1138. See Abernathy, supra note 5, at 342-43. If back pay awarded under a mandamus order bypasses the sovereign immunity obstacle, so should back pay awarded as part of injunctive reinstatement. See Freed, stupra note 42, at 407 . However, in Penn v. Schlesinger, 490 F.2d 700, 703-05 (1973), rev'd on other grounds, 497 F.2d 970 (1974) (en banc), the Fifth Circuit indicated that an action for back pay was not in the nature of a mandamus action, thereby leaving unclear whether mandamus will provide such recovery.

108. Decisions in two such suits have been reported. In Revis v. Laird, 391 F. Supp. $1133,1139-40$ (E.D. Cal. 1975), a $\$ 1981$ suit was brought against various federal officials in both their personal and official capacities. Following Bowers v. Campbell, 505 F.2d 1155 (9th Cir. 1974), and Beale v. Blount, 461 F.2d 1133 (5th Cir. 1972), the court rejected sovereign immunity as an absolute defense, but approved it as a possible limitation on the relief afforded. However, the court confused sovereign and executive immunity, citing Scheucr v. Rhodes, 416 U.S. 232 (1974), for the proposition that "[sovereign immunity] may provide a defense of varying degrees to the executive officers involved . ..." Since the officers were sued in both their individual and official capacities, the court should have treated the suit as two separate actions. Insofar as the suit is against the officials in their individual capacitics, it is the doctrine of qualified executive immunity, not sovereign immunity, that may provide a defense. And Scheuer has nothing to do with sovereign immunity. See pp. 526-29 supra.

In Miller v. Saxbe, 396 F. Supp. 1260 (D.D.C. 1975), Judge Gesell avoided the problems posed by a double-bladed $\$ 1981$ suit by ruling that the 1972 amendments to 'Title VII preempted $\$ 1981$ as a cause of action against the officers in their official capacities. He dismissed the plaintiffs' $\$ 1981$ claims against the United States for back pay and promotions, but allowed their $\$ 1981$ claims against the individual defendants for damages and injunctive relief to proceed. He also indicated that the defendants' claim of immunity would be tested under the Scheuer-Wood standard. In denying the defendants' subsequent motion for summary judgment, Judge Gesell reaffirmed the applicability of the Scheuer test. Miller v. Saxbe, 403 F. Supp. 1314, 1315-16 (D.D.C. 1975).

109. The recovery of back pay from the Government would necessarily reduce the deterrent effect of the $\$ 1981$ action against the official in his personal capacity. In many cases, however, the interests of compensating the victim of the discrimination and 
the burden on the official, thereby eliminating the need for indemnification, increasing the willingness of the jury to award damages, and at the same time retaining the deterrent effect of personal liability. This suggestion, of course, can only be tentative. It is too early to recommend precise guidelines for the implementation of the $\S 1981$ damage remedy for federal employment discrimination.

reducing the official's burden would justify such an apportionment of liability. It is difficult to devise a formula which courts can use to apportion liability in cvery case, since at least four variables are involved: the ability of the official to pay, the amount of back pay assessed, the size of the damage award, and the cause of the discrimination. 